\title{
Seroprevalence Hepatitis B in Blood Donors at Lubumbashi, DR Congo (Case of Provincial Hospital Sendwe Reference)
}

\author{
Kabamba Nzaji Michel1, Kabwe Matanda Pascal'2, Kaki Khang Mariette2, Ilunga Kahaki Blaise², \\ Nkongal Nkongal Tonny33, Bwana Kangulu Ignace, , Kilolo Ngoy Umba Elie4, \\ Kabyla Benjamin Ilunga ${ }^{5}$, Luboya Numbi Oscar ${ }^{5}$
}

\footnotetext{
${ }^{1}$ Department of Public Health, Faculty of Medicine, University of Kamina, Kamina, Democratic Republic of Congo

${ }^{2}$ Nursing, Higher Institute of Medical Techniques of Lubumbashi, Lubumbashi, Democratic Republic of Congo

${ }^{3}$ Nursing, Higher Institute of Medical Techniques Kolwezi, Kolwezi, Democratic Republic of Congo

${ }^{4}$ Department of Obstetrics and Gynecology, Faculty of Medicine, University of Kamina, Kamina, Democratic Republic of Congo

${ }^{5}$ Department of Public Health, Faculty of Medicine, Lubumbashi University, Lubumbashi, Democratic Republic of Congo

Email: michelnzaji@yahoo.fr
}

How to cite this paper: Michel, K.N., Pascal, K.M., Mariette, K.K., Blaise, I.K., Tonny, N.N., Ignace, B.K., Elie, K.N.U., Ilunga, K.B. and Oscar, L.N. (2016) Seroprevalence Hepatitis B in Blood Donors at Lubumbashi, DR Congo (Case of Provincial Hospital Sendwe Reference). Open Access Library Journal, 3: e3105.

http://dx.doi.org/10.4236/oalib.1103105

Received: October 17, 2016

Accepted: November 25, 2016

Published: November 29, 2016

Copyright $\odot 2016$ by authors and Open Access Library Inc.

This work is licensed under the Creative Commons Attribution International

License (CC BY 4.0).

http://creativecommons.org/licenses/by/4.0/

\begin{abstract}
In developing countries or economies in transition, many people die because of lack of safe blood, even in some urban healthcare facilities. Blood transfusions can save lives and improve health, but millions of patients did not timely access to safe blood, due to no reliable blood donors. The objective of this study was to determine the prevalence of hepatitis B in blood donors from the Sendwe General Provincial Hospital. This is a retrospective cross-sectional descriptive study on serum markers of hepatitis B study taking place over a period of 12 months from 1 January to 31 December 2014. This study showed that the prevalence of hepatitis B was $6.8 \%$, and $78.7 \%$ of donors were male. The mean age was $34.1 \pm 7.4$ years, ranging from 18 to 57 years. Married, family donors, blood type $\mathrm{O}$ and $\mathrm{Rh}$ positive were the most represented with $81.1 \%, 68.6 \%, 58.8 \%$ and $99.3 \%$ respectively. A significant association was observed between the prevalence of hepatitis B and age, civil status of blood donors $(p \leq 0.001)$. These results should encourage health authorities to the implementation of effective prevention methods to stop the rapid spread of this infection, which is a serious public health problem.
\end{abstract}

\section{Subject Areas}

Public Health

\section{Keywords}

Seroprevalence, Hepatitis B, Donors 


\section{Introduction}

Blood transfusion is a medical therapeutic act but it also creates the risk of transmission of infectious agents transmissible through blood to recipients despite advances in blood safety. Therefore, it is essential to detect these infectious agents to prevent transmission. Routine screening for HIV, hepatitis B (HBV) and C (HCV) and Treponema pallidum, on all donated blood and blood collection, are among the four major elements of the strategy adopted by WHO in blood safety.

Two billion people worldwide have serologic evidence of HBV infection currently or in the past and 350 million are chronically infected and at risk of developing liver disease associated with HBV. Approximately 15\% - 40\% of chronically infected patients develop cirrhosis, progressing to liver failure and/or hepatocellular carcinoma. Infection with HBV is between 500,000 and 1,200,000 deaths annually. HBV prevalence varies significantly in different regions of the world [1]. In Sub-Saharan Africa, the prevalence of hepatitis B among blood donors ranges from 9.2\% in the Democratic Republic of Congo and $10.7 \%$ in Cameroon [2]. The objective of this study was to determine the prevalence of hepatitis B in blood donors through the data from the Sendwe General Provincial Hospital.

\section{Materials and Methods}

\subsection{Site of the Study}

Located in the health zone of Lubumbashi, the provincial General Hospital Jason Sendwe is located in the town of Lubumbashi. It is bounded on the north by the Sendwe Avenue, south by the school Avenue, in the east by the Wema High school and West by the Likasi Avenue. Hospital Sendwe with its capacity of 1200 beds is ranked second after the Kinshasa General Hospital, it serves virtually the population of all municipalities in Lubumbashi, but also from the rest of Katanga, two Kasai and South Kivu.Given its importance despite having 1200 beds with an occupancy rate of $66.3 \%$.

\subsection{Design of the Study}

This is a retrospective cross-sectional descriptive study on serum markers of hepatitis B study took place over a period of 12 months period from 1 January to 31 December 2014. Our target population is all volunteer blood donors, family and paid Along with this health facility during 2014. Consisting of 1421 donors, our sampling is complete. Included in the study all blood donors (volunteers, family, paid) recorded in the Laboratory of reference Sendwe General Provincial Hospital for a first donation. Serodiagnosis on each donation was made by the Abbott Determine HBsAg TM.

The collected data were coded, entered, processed and analyzed using the Epi-Info software 7. The descriptive analysis was performed through the calculation of proportions for categorical variables and the different frequency comparisons were encrypted to using the Chi-square test of Pearson and Fisher's exact test when necessary. We set the p statistical significance $<0.05$. Variables used in this study are: age, sex, civil status, 
Categories donor, Blood and RhesusGroup, Status of donor hepatitis B.

This study was approved by related ethics committee besides and mothers sign informed consent and have a whole understanding of this study. Our study had no binding character. Any information collected from donors has been and will remain confidential. Similarly, the names of participants will remain confidential and will not be mentioned in the presentation of results or associated to results in any way whatsoever. They will also be disclosed to any third party.

\section{Results}

Out of a total of 1421 blood donors in 1119 or $78.7 \%$ are male and 302 or $21.3 \%$ were male, the sex ratio is about 3.7/1. The mean age was $34.1 \pm 7.4$ years, ranging from 18 to 57 years. The majority of donors $91.5 \%$ were aged between 19 and 45 years. Related to civil status, the category of donors, blood group and rhesus, it appears that married, family donors, blood type $\mathrm{O}$ and $\mathrm{Rh}$ positive are the most represented with $81.1 \%$, respectively, $68 \%, 6 \%, 58.8 \%$ and $99.3 \%$ (Table 1 ).

Table 1. Breakdown by socio-demographic characteristics of blood donors.

\begin{tabular}{|c|c|c|}
\hline Factors studied & Effective & Percentage \\
\hline \multicolumn{3}{|l|}{ Age } \\
\hline$\leq 18$ years & 3 & $0.2 \%$ \\
\hline $19-45$ years & 1300 & $91.5 \%$ \\
\hline$\geq 46$ years & 118 & $8.3 \%$ \\
\hline \multicolumn{3}{|l|}{ Sex } \\
\hline Female & 302 & $21.3 \%$ \\
\hline Male & 1119 & $78.7 \%$ \\
\hline \multicolumn{3}{|l|}{ Civil status } \\
\hline Single & 269 & $18.9 \%$ \\
\hline Married & 1152 & $81.1 \%$ \\
\hline \multicolumn{3}{|l|}{ Categories donor } \\
\hline Volunteer & 230 & $16.2 \%$ \\
\hline Family & 975 & $68.6 \%$ \\
\hline Paid & 216 & $15.2 \%$ \\
\hline \multicolumn{3}{|l|}{ Blood group } \\
\hline $\mathrm{A}$ & 341 & $24.0 \%$ \\
\hline $\mathrm{AB}$ & 46 & $3.2 \%$ \\
\hline $\mathrm{B}$ & 199 & $14.0 \%$ \\
\hline $\mathrm{O}$ & 835 & $58.8 \%$ \\
\hline \multicolumn{3}{|l|}{ Rhesus } \\
\hline Negative & 10 & $0.7 \%$ \\
\hline Positive & 1411 & $99.3 \%$ \\
\hline
\end{tabular}


From Table 2 that the seroprevalence of hepatitis B is $6.8 \%$ while it is around $3.2 \%$, $1.7 \%$ and $1 \%$ for HIV, HCV and syphilis.

From Table 3 that the highest prevalence was observed in donors of $\leq 18$ (66.7\%), single (13.4\%), paid donors (8.8\%), those sex male (7.0\%), people of blood group A (8.5\%) and those of Rh positive (6.9\%).

Table 4 shows that donors infected with HBV are younger than those who are not infected.

Table 5 shows that there is no significant association between the prevalence of hepatitis B and socio-demographic characteristics such as gender, category of donors, blood group and rhesus blood donor. However, a significant association was observed between the prevalence of hepatitis B and the age and marital status of blood donors ( $p$ $\leq 0.001)$.

Table 2. Seroprevalence of HIV, HBV, HCV and syphilis among blood donors.

\begin{tabular}{ccccc}
\hline Types of viruses & Total number & Number of cases & Prevalence in\% & CI 95\% \\
\hline HIV & 1421 & 46 & 3.2 & {$[2.4 \%-4.3 \%]$} \\
VHB & 1421 & 97 & 6.8 & {$[5.6 \%-8.3 \%]$} \\
HCV & 1421 & 24 & 1.7 & {$[1.1 \%-2.5 \%]$} \\
Syphilis & 1421 & 14 & 1.0 & {$[0.6 \%-1.7 \%]$} \\
\hline
\end{tabular}

Table 3. Seroprevalence of hepatitis B according to the sociodemographic characteristics of blood donors.

\begin{tabular}{|c|c|c|c|}
\hline Factors studied & Total workforce & Number of cases & Prevalence in $\%$ \\
\hline \multicolumn{4}{|l|}{ Age } \\
\hline$\leq 18$ years & 3 & 2 & 66.7 \\
\hline $19-45$ years & 1300 & 89 & 6.9 \\
\hline$\geq 46$ years & 118 & 6 & 5.1 \\
\hline \multicolumn{4}{|l|}{ Sex } \\
\hline Female & 302 & 19 & 6.3 \\
\hline Male & 1119 & 78 & 7.0 \\
\hline \multicolumn{4}{|l|}{ Civil status } \\
\hline Single & 269 & 36 & 13.4 \\
\hline Married & 1152 & 61 & 5.3 \\
\hline \multicolumn{4}{|l|}{ Categories donor } \\
\hline Volunteer & 230 & 11 & 4.8 \\
\hline Family & 975 & 67 & 6.9 \\
\hline Paid & 216 & 19 & 8.8 \\
\hline \multicolumn{4}{|l|}{ Blood group } \\
\hline $\mathrm{A}$ & 341 & 29 & 8.5 \\
\hline $\mathrm{AB}$ & 46 & 2 & 4.4 \\
\hline B & 199 & 14 & 7.0 \\
\hline $\mathrm{O}$ & 835 & 52 & 6.2 \\
\hline \multicolumn{4}{|l|}{ Rhesus } \\
\hline Negative & 10 & 0 & 0.0 \\
\hline Positive & 1411 & 97 & 6.9 \\
\hline
\end{tabular}


Table 4. Comparison of average age of infected donors and not infected with HB.

\begin{tabular}{cccc}
\hline \multirow{2}{*}{ Status of the donor } & \multicolumn{2}{c}{ VHB } & $\mathrm{p}$ \\
\cline { 2 - 3 } & Middle age & Extremes & \\
\hline Positive & $32.4 \pm 7.1$ years & $18-47$ years & 0.01 \\
Negative & $34.3 \pm 7.4$ years & $18-57$ years & \\
\hline
\end{tabular}

Table 5. Association between socio-demographic characteristics and the seroprevalence of HBV in blood donors.

\begin{tabular}{|c|c|c|c|c|c|}
\hline \multirow{2}{*}{ Factors studied } & \multicolumn{2}{|c|}{ VHB } & \multirow{2}{*}{$\begin{array}{c}\text { Chi-Square } \\
\text { Test }\end{array}$} & \multirow{2}{*}{$\begin{array}{c}\text { IC } \\
95 \%\end{array}$} & \multirow{2}{*}{$\mathrm{p}$} \\
\hline & Positive & Negative & & & \\
\hline \multicolumn{6}{|l|}{ Age } \\
\hline$\leq 18$ years & $2(66.7 \%)$ & $219(33.3 \%)$ & \multirow{3}{*}{17,45} & \multirow{3}{*}{ - } & \multirow{3}{*}{$\leq 0.001$} \\
\hline 19 - 45 years & $89(6.9 \%)$ & $1211(93.1 \%)$ & & & \\
\hline$\geq 46$ years & $6(5.1 \%)$ & $112(94.9 \%$ & & & \\
\hline \multicolumn{6}{|l|}{ Sex } \\
\hline Female & $19(6.3 \%)$ & $283(93.7 \%)$ & \multirow{2}{*}{0.17} & \multirow{2}{*}{$\begin{array}{c}1.12 \\
{[0.65 \text { to } 1.94]}\end{array}$} & \multirow{2}{*}{0.68} \\
\hline Male & $78(7.0 \%)$ & $1041(93.0 \%)$ & & & \\
\hline \multicolumn{6}{|l|}{ Civil status } \\
\hline Single & $36(13.4 \%)$ & $233(86.4 \%)$ & \multirow{2}{*}{22.43} & 2.76 & \multirow{2}{*}{$\leq 0.001$} \\
\hline Married & $61(5.3 \%)$ & $1091(94.7 \%)$ & & [1.75 to 4.36$]$ & \\
\hline \multicolumn{6}{|l|}{ Categories donor } \\
\hline Volunteer & $11(4.8 \%)$ & $219(95.2 \%)$ & \multirow{3}{*}{2.83} & & \multirow{3}{*}{0.24} \\
\hline Family & $67(6.9 \%)$ & $908(93.1 \%)$ & & - & \\
\hline Paid & $19(8.8 \%)$ & $197(91.2 \%)$ & & & \\
\hline \multicolumn{6}{|l|}{ Blood group } \\
\hline $\mathrm{A}$ & $29(8.5 \%)$ & $312(91.5 \%)$ & \multirow{4}{*}{2.44} & \multirow{4}{*}{ - } & \multirow{4}{*}{0.49} \\
\hline $\mathrm{AB}$ & $2(4.4 \%)$ & $44(95.6 \%)$ & & & \\
\hline B & $14(7.0 \%)$ & $185(93.0 \%)$ & & & \\
\hline $\mathrm{O}$ & $52(6.2 \%)$ & $783(93.8 \%)$ & & & \\
\hline \multicolumn{6}{|l|}{ Rhesus } \\
\hline Negative & $0(0.0 \%)$ & $10(100 \%)$ & \multirow{2}{*}{0.74} & & \multirow[b]{2}{*}{0.50} \\
\hline Positive & $97(6.9 \%)$ & $1314(93.1 \%)$ & & & \\
\hline
\end{tabular}

\section{Discussion}

We noted a male predominance in our study (78.7\%). The breakdown of donors by sex varies by country. We noted a male predominance in Madagascar, as in other countries such as Burkina Faso, Tanzania, Eritrea, Greece, northern India. In other countries like Britain have a female predominance. The male can be explained by typical African be- 
lief stating that men are healthier and stronger than women [3]. Obstetric gynecology factors such as menstrual cycles, pregnancy, breastfeeding may also influence this trend. These factors may prevent many women to donate blood.

This study found a prevalence of HBV, 6.8\%, which is close to Batina [4], Kisangani, and all by Baleka [5] Kinshasa and Koné and all [6] in Mali. The highest values were obtained in the meta analysis Nigerian Musa and all who found a value of $14 \%$ of voluntary blood donors [7] in the study and all Tanko Ghana [8], that of Cameroon made by Noah Noah [9], and all of Viet in Vietnam [10]. Lower prevalences were found; $4.68 \%$ in the Ivory Coast by N'DriN'Guessan [11], 3.21\% in Madagascar by Rakotoniaina In India in the study and all Bamanahali in Karnataka, which had 2.12\% [12], Secunderabad in that of Sukruthra 2009 and all that gives 1.28\% [13], Pakistan, Syed Mukhtar was $1.97 \%$ [14], Congo in Kamina in the study of Kabamba and Kabila with $1.6 \%$ [15] Bukavu and that of 3.7\% made by all and Namululi [16]. In Namibia found that $0.6 \%$ Mavenyengwa and all [17], $0.39 \%$ in Iran and all that is Mohammadali [18]. This figure reflects the high endemicity of hepatitis B virus in the population studied. It also confirms the presence of hepatitis B in the general population in the DRC. We believe that highly endemic countries are generally countries with low levels of hygiene and is a strong or high transmission of STIs. Probably the high prevalence of hepatitis B is linked to sanitation and the lack of sufficient prevention of STIs in our midst.

Our study showed that female blood donors had a prevalence of $6.3 \%$, while it was in the order of $7.0 \%$ among males, but this difference was not statistically significant. This can be explained by way of sexual transmission of this viral disease. The explanation we can advance for males compared to females is the role of socio-cultural characteristics present only in men, such as circumcision. But other reasons may be a possibility of porting from birth with the mother to child transmission, blood transfusions and other ritual scarification.

In terms of the category of donors, it should be noted that in pay and family donors, the prevalence of hepatitis B was $8.8 \%$ and $6.9 \%$ respectively, while it is $4.8 \%$ among volunteer donors without this statistically significant. This can be explained by the fact that most blood donations in Sub-Saharan Africa is done by family members of the recipient.

The highest prevalence was in the age group $\leq 18$ years $(66.7 \%)$. This study showed that donors whose age is equal to or less than 18 was predominant, income close to the study of Ghana found that the age group between 10 to 20 years [8]. And that of Batina takes the age group 17 to 24 years [4]. This high prevalence of hepatitis B among youth suggests a serious public health problem because of HIV status HBsAg may explain the occurrence of cirrhosis or hepatocellular carcinoma of the liver.

\section{Conclusions}

Carriage prevalence of HBsAg among blood donors is high and warrants routine screening of this serum marker in every blood donor to reduce transfusion risk. Our study shows that $78.7 \%$ of donors were male. The mean age was $34.1 \pm 7.4$ years, rang- 
ing from 18 to 57 years. Married, family donors, blood type $\mathrm{O}$ and $\mathrm{Rh}$ positive were the most represented with $81.1 \%, 68.6 \%, 58.8 \%$ and $99.3 \%$ respectively. Our results showed that hepatitis B is common among blood donors at the Provincial Janson Sendwe hospital with a prevalence of $6.8 \%$.

Implementation of strategies for transfusion safety, including a provision based on voluntary blood donation and unpaid, effective public education about blood donation, donor selection and quality assured screening applied to all the blood, can prevent transmission of HBV. The prevention of hepatitis B can also be passed by immunoprophylaxis, by vaccinating people at risk of this major public health problem.

\section{References}

[1] Forde, K.A., Tanapanpanit, O. and Rajender Reddy, K. (2015) Hepatitis B and C in African Americans: Current Status and Continued Challenge. Clinical Gastroenterology and Hepatology, 12, 738-748.

[2] Noah Noah, D. (2011) HBs Antigen Prevalence in Blood Donors and the Risk of Transfusion of Hepatitis B at the Central Hospital of Yaounde, Cameroon. Open Journal of Gastroenterology, 1, 23-27. http://dx.doi.org/10.4236/ojgas.2011.12004

[3] R. A. Rakotoniaina A.I., Randriamanantany, Z.A., Ranaivosoa, K.H.M., Andriambelo, V., Fortuné, H. and Rakoto Alson, O.A. (2013) Prevalence of HIV, HBV, HCV and Treponema pallidum in Donors of Voluntary Blood at the National Blood Transfusion Centre of Antananarivo from 1992 to 2010. Medical Journal of Madagascar, 3, 264-268.

[4] Batina Agasa, S., Gulbis, B., Dramaix, M.W. and Losimba Likwela, J. (2013) Evolution of Markers of Viral Infections Transmitted by Transfusion from 2005 to 2008 in Kisangani, Democratic Republic of Congo. Medical Journal of Great Lakes, 2, 283-292.

[5] Baleka, F., Pukuta, E., Lay, Y., Mwema, G., Mumba, M. and TJJ, M. (2010) Prévalence et co-infection de VIH, VHC et VHB chez les donneurs de sang à Kinshasa, RDC. [Baleka, F., Pukuta, E., Lay, Y., Mwema, G., Mumba, M. and TJJ, M. (2010) Prevalence and Co-Infection of HIV, HCV and HBV in Blood Donors in Kinshasa, DRC.] Congo Sciences, 1, 1-4.

[6] Koné, M.C., Sidibé, E.T., Mallé, K.K., Beye, S.A., Lurton, G., Dao, S., Diarra, M.T. and Dao, S. (2012) Seroprevalence of HIV and Hepatitis B and C among Blood Donors in Segou (Mali). Tropical Medicine and Health, 22, 97-98.

[7] Musa, B.M., Bussell, S., Borodo, M.M., Samaila, A.A. and Femi, O.L. (2015) Prevalence of Hepatitis B Virus Infection in Nigeria, 2000-2013: A Systematic Review and Meta-Analysis. Nigerian Journal of Clinical Practice, 18, 163-172.

http://dx.doi.org/10.4103/1119-3077.151035

[8] Rufai, T., Mutocheluh, M., Kwarteng, K. and Dogbe, E. (2014) The Prevalence of Hepatitis B Virus E Antigen among Ghanaian Blood Donors. Pan African Medical Journal, 17, 1-4. http://dx.doi.org/10.11604/pamj.2014.17.53.3390

[9] Noah, D.N., Njouom, R., Bonny, A., Pirsou, P., Meli, J. and Biwole Sida, M. (2011) HBs Antigen Prevalence in Blood Donors and the Risk of Transfusion of Hepatitis B at the Central Hospital of Yaounde, Cameroon. Open Journal of Gastroenterology, 1, 23-27. http://dx.doi.org/10.4236/ojgas.2011.12004

[10] Viet, L., Lan, N.T.N., Husum, H., et al. (2012) Prevalence of Hepatitis B \& Hepatitis C Virus Infections in Potential Blood Donors in Rural Vietnam. Indian Journal of Medical Research, 136, 74-81.

[11] N'dri, N., Thot'o, A.S., Okon, A.J.-B., et al. (2013) Prevalence of HBsAg among Blood Do- 
nors in Transfusion Center, Abidjan (Ivory Coast). Open Journal of Gastroenterology, 3, 165-169. http://dx.doi.org/10.4236/ojgas.2013.33027

[12] Bommanahalli, B., Rudramma, J., Mallikarjuna Swamy, C.M., Gouda, K., Siddartha, K. and Shashikala, K.P. (2014) Seroprevalence of Hepatitis B and Hepatitis C Viral Infections among Blood Donors of Central Karnataka, India. International Journal of Medical Science and Public Health, 3, 272-275.

[13] Batina Agasa, S., Gulbis, B., Wilmet Dramaix, M. and Losimba Likwela, J. Evolution of Markers of Viral Infections Transmitted by Transfusion from 2005 to 2008 in Kisangani, Democratic Republic of Congo. Medical Journal of Great Lakes, 2, 283-292.

[14] Ali, S.M., I.U., Khattak, I.U., Ali, A. and Tariq, M. (2010) Seropositivity for Hapatitis B and C in Voluntary Blood Donors. Journal of Ayub Medical College Abbottabad, 22, 149-151.

[15] Nzaji, M.K. and Ilunga, B.K. (2013) A Study of the Prevalence of Infectious Markers in Blood Donors in Rural Areas. The Case of Kamina Hospital. Public Health, 25, 213-217.

[16] Namululi, B., Guerrieri, C. and Dramaix, M.W. (2012) Impact of Blood Donor Recruitment Method on the Prevalence of HIV and HBV in Bukavu, Democratic Republic of Congo Impact of Method of Recruitment of Blood Donors on the Prevalence of HIV. Infectious Diseases and Medicine, 22, 69-74.

[17] Mavenyengwa, R.T., Munyaradzi, M., Chipare, I. and Shoombe, E. (2014) Prevalence of Human Immunodeficiency Virus, Syphilis, Hepatitis B and C in Blood Donations in Namibia. BMC Public Health, 14, 1-7. http://dx.doi.org/10.1186/1471-2458-14-424

[18] Mohammadali, F. and Pourfathollah, A. (2014) Association of ABO and Rh Blood Groups to Blood-Borne Infections among Blood Donors in Tehran-Iran. Iranian Journal of Public Health, 43, 981-989.

\section{Submit or recommend next manuscript to OALib Journal and we will provide best service for you:}

- Publication frequency: Monthly

- 9 subject areas of science, technology and medicine

- Fair and rigorous peer-review system

- Fast publication process

- Article promotion in various social networking sites (LinkedIn, Facebook, Twitter, etc.)

- Maximum dissemination of your research work

Submit Your Paper Online: Click Here to Submit

Or Contact service@oalib.com 